\title{
Penerapan Metode Balanced Scorecard dan Analytical Hierarcy Process (AHP) Dalam Penentuan Karyawan Berprestasi (Studi Kasus : Kantor Pertanahan Kota Pekanbaru)
}

\author{
Dega Aguansyah \\ Program Studi Teknik Industri, Fakultas Teknik, Universitas Muhammadiyah Riau \\ Jalan Tuanku Tambusai Ujung, Kecamatan Tampan, Kelurahan Delima, Kota Pekanbaru, Riau 28291 \\ E-mail: degasii37@gmail.com
}

\begin{abstract}
The National Land Agency (abbreviated BPN in Indonesian) is a non-ministerial government institution that is under and responsible to the President and led by the Head (in accordance with Presidential Decree No. 63 of 2013). The problems that occur at the Pekanbaru Land Office in determining outstanding employees are only seen based on the results of the work they do, not based on the criteria for each employee. Therefore, this study was conducted to provide application in determining outstanding employees with more detailed results based on the criteria of each employee using several methods, including the Balanced Scorecard method and the Analytical Hierarchy Process (AHP). Based on the research results, it is known that based on the Balanced Scorecard method, the criteria to be used are Comprehension, Accuracy, Craft, and Discipline with the same highest value, namely 12.25. After that, each employee was assessed based on the criteria using the Analytical Hierarchy Process (AHP) method with the highest score being DHEA with a value of 0.301 .
\end{abstract}

Keywords: Outstanding Employees, Balanced Scorecard, Analytical Hierarcy Process (AHP)

\begin{abstract}
Abstrak
Badan Pertanahan Nasional (BPN) adalah Lembaga Pemerintah Non Kementrian yang berada di bawah dan bertanggung jawab kepada Presiden dan dipimpin oleh Kepala. (Sesuai dengan Perpres No. 63 Tahun 2013). Permasalahan yang terjadi pada Kantor Pertanahan Kota Pekanbaru dalam menentukan karyawan berprestasi hanya dilihat berdasarkan hasil dari kerja yang mereka lakukan, dan tidak dilihat berdasarkan kriteria pada masing-masing karyawan juga. Oleh karena itu, penelitian ini dilakukan untuk memberikan penerapan dalam menentukan karyawan berprestasi berdasarkan hasil yang lebih detail berdasarkan kriteria masing-masing karyawan dengan menggunakan beberapa metode yang diantaranya adalah metode Balanced Scorecard dan Analytical Hierarcy Process (AHP). Berdasarkan hasil penelitian diketahui bahwa berdasarkan metode Balanced Scorecard kriteria yang akan digunakan adalah Pemahaman, Ketelitian, Kerajinan, dan Kedisiplinan dengan nilai tertinggi yang sama yaitu 12,25. Setelah itu masing-masing karyawan dilakukan penilaian berdarkan kriteria menggunakan metode Analytical Hierarcy Process (AHP) dengan hasil nilai tertinggi adalah Dhea dengan hasil nilai 0,301.
\end{abstract}

Kata kunci: Karyawan Berprestasi, Balanced Scorecard, Analiytical Hierarcy Process (AHP)

\section{Pendahuluan}

Karyawan yang memiliki kemampuan yang baik dan profesional sangat mungkin mempunyai prestasi kerja dalam melaksanakan tugasnya, sehingga lebih berdaya guna. Karyawan berprestasi dapat diartikan sebagai seseorang yang memiliki tingkat produktivitas yang sempurna sehingga memiliki daya guna dan loyal dalam melaksanakan tugasnya. Dalam penentuan karyawan berprestasi di Kantor
Pertanahan Kota Pekanbaru terdapat faktorfaktor yang menjadi penilaian. Demi meningkatkan kinerja dan produktivitas kerja maka pengambilan keputusan karyawan berprestasi sangatlah diperlukan. Dalam mengambil keputusan terhadap pemilihan karyawan berprestasi pada Kantor Pertanahan Kota Pekanbaru masih menerapkan sistem manual yaitu penilaian ini hanya berdasarkan pada penilaian kinerjanya saja. Untuk itu, perlu 
dilakukan penelitian tentang kinerja karyawan secara menyeluruh menggunakan Balanced Scorecard dan Analytical Hierarcy Process dengan tujuan untuk mengetahui kriteria yang dapat dijadikan acuan penentuan karyawan berprestasi dengan menggunakan metode Balanced Scorecard, dan untuk mengetahui karyawan PPNPN yang berprestasi dalam sistem perankingan dengan menggunakan metode AHP.

\section{Metodologi}

Pengambilan keputusan adalah suatu peristiwa yang meliputi diagnosa dari suatu implementasi dalam pengambilan tindakan dan implementasi. Setelah dilakukan implementasi metode yakni melakukan pengolahan data dengan metode Balanced Scorecard (BSC) dengan metode Analytical Hierarchy Process (AHP), Selanjutnya dilakukan Analisis data, adapun analisis data yang dilakukan sebagai berikut: Analisis Identifikasi Bobot dan Target Kriteria, Serta Penentuan Konsistensi Data dalam Pemilihan Karyawan Berprestasi menggunakan metode Balanced Scorecard dan Penentuan Urutan Prioritas Masing-Masing Karyawan Berprestasi Menggunakan Metode AHP.

Dalam penentuan kriteria dalam pemilihan karyawan berprestasi pada penelitian ini dilakukan penyebaran kuisioner kepada beberapa Kepala Seksi dan Kepala Urusan di tiap-tiap seksi ruangan. Berikut ini beberapa kriteria yang akan digunakan dalam penentuan karyawan berprestasi :

Tabel 1.

Kriteria dalam penentuan karyawan berprestasi

\begin{tabular}{|c|c|l|}
\hline No & Variabel & \multicolumn{1}{|c|}{ Kriteria } \\
\hline 1 & Pemahaman & $\begin{array}{l}\text { Petugas memahami tugas } \\
\text { sesuai pekerjaan yang } \\
\text { diberikan }\end{array}$ \\
\hline 2 & $\begin{array}{c}\text { Tepat } \\
\text { Waktu }\end{array}$ & $\begin{array}{l}\text { Petugas melakukan } \\
\text { pekerjaannya dengan tepat } \\
\text { waktu }\end{array}$ \\
\hline 3 & Ketelitian & $\begin{array}{l}\text { Petugas mampu } \\
\text { menyelesaikan tugas tanpa } \\
\text { melakukan kesalahan }\end{array}$ \\
\hline 4 & Kerajinan & $\begin{array}{l}\text { Petugas melakukan tugas } \\
\text { sesuai jadwal }\end{array}$ \\
\hline 5 & Keahlian & $\begin{array}{l}\text { Petugas mampu } \\
\text { menggunakan alat atau } \\
\text { perlengkapan yang }\end{array}$ \\
\hline
\end{tabular}

\begin{tabular}{|c|c|l|}
\hline & & menunjang pekerjaan \\
\hline 6 & Kebersihan & $\begin{array}{l}\text { Petugas memelihara } \\
\text { perlengkapan kerja dengan } \\
\text { baik }\end{array}$ \\
\hline 7 & Kerjasama & $\begin{array}{l}\text { Petugas mampu bekerja } \\
\text { sama dengan atasan dan } \\
\text { rekan kerja }\end{array}$ \\
\hline 8 & Kedisiplinan & $\begin{array}{l}\text { Kehadiran petugas ke } \\
\text { kantor dengan baik }\end{array}$ \\
\hline
\end{tabular}

Data pada kuisioner yang diberikan bersifat kualitatif, setelah seluruh data terkumpul kemudian data tersebut diubah menjadi data kuantitatif dengan cara memberikan pembobotan pada masing-masing pilihan jawaban yang diberikan oleh responden dengan pemberian skor sebagai berikut :

Sangat Tidak Setuju (STS) = skor 1

Tidak Setuju (TS) = skor 2

Kurang Setuju (KS) = skor 3

Sejutu (S) = skor 4

Sangat Setuju (SS) = skor 5

Pemberian skor bertujuan untuk memberikan kemudahan untuk mengolah data dan menentukan tingkat kepuasan pelanggan. Semua kuesioner yang kembali syarat untuk diolah dan dilakukan analisis.

Kuisioner diberikan kepada 20 responden yang bersangkutan, dimana masing-masing responden sudah dilakukan perhitungan $\mathrm{Uji}$ Validitas dan Uji Realibilitas dengan keseluruhan data yang hasilnya telah valid dan reliable dan dapat dilanjutkan ke tahap selanjutnya.

\section{Hasil dan Pembahasan}

\subsection{Hasil}

\subsubsection{Pembobotan Balanced Scorecard}

Permberian besar bobot untuk masingmasing perspektif ditentukan berdasarkan tingkat kepentingan perspektif tersebut terhadap suatu kriteria. Kantor Pertanahan Kota Pekanbaru menetapkan bahwa setiap perspektif memiliki tingkat kepentingan yang sama terhadap penentuan karyawan berprestasi, yaitu masingmasing sebesar 12,5. Pembobotan pada tiap kriteria terdapat pada tabel dibawah ini : 
Tabel 2.

Nilai bobot dan target di tiap kriteria

\begin{tabular}{|l|c|c|}
\hline \multicolumn{1}{|c|}{ Kriteria } & Bobot & $\begin{array}{c}\text { Target } \\
\%\end{array}$ \\
\hline $\begin{array}{l}\text { Petugas memahami } \\
\text { tugas sesuai } \\
\text { pekerjaan yang } \\
\text { diberikan } \\
\text { (Pemahaman) }\end{array}$ & 12,5 & $100 \%$ \\
\hline $\begin{array}{l}\text { Petugas melakukan } \\
\text { pekerjaannya dengan } \\
\text { tepat waktu } \\
\text { (Ketepatan Waktu) }\end{array}$ & 12,5 & $100 \%$ \\
\hline $\begin{array}{l}\text { Petugas mampu } \\
\text { menyelesaikan tugas } \\
\text { tanpa melakukan } \\
\text { kesalahan } \\
\text { (Ketelitian) }\end{array}$ & 12,5 & $100 \%$ \\
\hline $\begin{array}{l}\text { Petugas melakukan } \\
\text { tugas sesuai jadwal } \\
\text { (Ketepatan Waktu) }\end{array}$ & 12,5 & $100 \%$ \\
\hline $\begin{array}{l}\text { Petugas mampu } \\
\text { menggunakan alat } \\
\text { atau perlengkapan } \\
\text { yang menunjang } \\
\text { pekerjaan (Keahlian) }\end{array}$ & 12,5 & $100 \%$ \\
\hline $\begin{array}{l}\text { Petugas memelihara } \\
\text { perlengkapan kerja } \\
\text { dengan baik } \\
\text { (Kebersihan) }\end{array}$ & 12,5 & $100 \%$ \\
\hline $\begin{array}{l}\text { Petugas mampu } \\
\text { bekerja sama dengan } \\
\text { atasan dan rekan } \\
\text { kerja (Kerjasama) }\end{array}$ & 12,5 & $100 \%$ \\
\hline $\begin{array}{l}\text { Kehadiran petugas ke } \\
\text { kantor dengan baik } \\
\text { (Kedisiplinan) }\end{array}$ & 12,5 \\
\hline
\end{tabular}

\section{1,2 Interval}

Setelah melakukan analisis data masingmasing perspektif, nilai atau skor tiap perspektif diberikan pembobotan. Hasil dari perhitungan bobot keseluruhan perspektif diberikan interval penilaian yang akan menunjukkan tingkat dari kinerja perusahaan secara keseluruhan pada nilai yang baik atau buruk. Hasil perhitungan dari seluruh perspektif adalah sebagai berikut:

$$
\begin{aligned}
\text { IKmaks } & =\mathrm{PP} \times \mathrm{R} \times \text { EXmaks } \\
& =1 \times 20 \times 5 \\
& =100 \\
\text { IKmin } & =\mathrm{PP} \times \mathrm{R} \times \mathrm{EXmin} \\
& =1 \times 20 \times 1 \\
& =20 \\
\text { Interval } & =(100-20): 5 \\
& =16
\end{aligned}
$$

\subsubsection{Kepentingan Kriteria dengan Perspektif Balanced Scorecard \\ Pada tahap ini dilakukan pengambilan} data yang berkaitan dengan hal-hal yang mempengaruhi tingkat kepentingan kriteria dalam penentuan karyawan berprestasi. Pengumpulan data dilakukan dengan beberapa metode yang akan menunjang akurasi dari perhitungan kinerja perusahaan.

Adapun rumus dalam perhitungan kriteria dengan perspektif Balanced Scorecard tersebut adalah sebagai berikut :

1. Skor $=\mathrm{PP} \times \mathrm{R} \times \overline{\overline{\mathrm{X}}}$

Dimana :

$$
\begin{aligned}
\mathrm{PP} & =\text { Satuan Kriteria } \\
\mathrm{R} & =\text { Populasi } \\
\overline{\mathrm{X}} & =\text { Rata-rata per kriteria } \\
\text { 2. Realisasi } & =\frac{\text { Skor }}{\text { IKmaks }} \\
\text { 3. Skor Akhir } & =\text { Skor } \times\left(\frac{\text { Bobot }}{100}\right)
\end{aligned}
$$$$
\text { 2. } \text { Realisasi }=\frac{\text { Skor }}{\text { IKmaks }}
$$

Adapun rekapan nilai perspektif tersebut adalah sebagai berikut :

Tabel 3.

Rekapitulasi Nilai Perspektif Per-Variabel

\begin{tabular}{|l|c|c|c|c|c|}
\hline \multicolumn{1}{|c|}{ Variabel } & Bobot & Target & Realisasi & Skor & $\begin{array}{c}\text { Skor } \\
\text { Akhir }\end{array}$ \\
\hline Pemahaman & 12,5 & $100 \%$ & $98 \%$ & 98 & 12,25 \\
\hline $\begin{array}{l}\text { Ketepatan } \\
\text { Waktu }\end{array}$ & 12,5 & $100 \%$ & $96 \%$ & 96 & 12 \\
\hline Ketelitian & 12,5 & $100 \%$ & $94 \%$ & 94 & 11,75 \\
\hline Kerajinan & 12,5 & $100 \%$ & $98 \%$ & 98 & 12,25 \\
\hline Keahlian & 12,5 & $100 \%$ & $98 \%$ & 98 & 12,25 \\
\hline Kebersihan & 12,5 & $100 \%$ & $95 \%$ & 95 & 11,88 \\
\hline Kerjasama & 12,5 & $100 \%$ & $97 \%$ & 97 & 12,13 \\
\hline Kedisiplinan & 12,5 & $100 \%$ & $98 \%$ & 98 & 12,25 \\
\hline
\end{tabular}

Dalam perhitungan nilai kepentingan pada delapan kriteria dengan menggunakan Balanced Scorecard terdapat empat nilai kepentingan tertinggi yang memiliki nilai 12,25 , yaitu :

1. Petugas memahami tugas sesuai pekerjaan yang diberikan (Pemahaman).

2. Petugas mampu menyelesaikan tugas tanpa melakukan kesalahan (Ketelitian)

3. Petugas melakukan tugas sesuai jadwal (Kerajinan)

4. Kehadiran petugas ke kantor dengan baik (Kedisiplinan)

Dalam empat kriteria yang memiliki nilai tertinggi tersebut, maka dapat dijadikan acuan dalam penentuan karyawan berprestasi yang akan di lanjutkan ke dalam metode Analytichal Hierarchy Process (AHP) untuk menentukan 
karyawan yang memiliki nilai tertinggi terhadap empat kriteria tertinggi diatas.

\subsubsection{Perhitungan Metode Analytical Hierarchy Process (AHP)}

Sebelum masuk ke tahap metode AHP ditentukan suatu struktur hirarki berdasarkan kepentingan tertinggi yang sebelumnya didapat melalui perhitungan dengan metode Balanced Scorecard. Struktur hirarki terdiri dari tiga level yaitu tujuan atau goal, kriteria dan karyawan.

\subsubsection{Perhitungan Prioritas Kriteria}

Dalam perhitungan prioritas kriteria terdapat 6 perbandingan yang harus dilakukan yaitu perbandingan antara kriteria Pemahaman dengan kriteria Ketelitian, kriteria Pemahaman dengan kriteria Kerajinan, kriteria Pemahaman dengan kriteria Kedisiplinan, kriteria Ketelitian dengan kriteria Kerajinan, kriteria Ketelitian dengan kriteria Kedisiplinan, kriteria Kerajinan dengan jumlah Kedisiplinan. Adapun dari ke enam perbandingan tersebut dilakukan sebuah perhitungan yang terdapat pada metode Analytical Hierarcy Process (AHP), perhitungan tersebut diantaranya :

1. Matriks perbandingan berpasangan kriteria

2. Hasil pembagian matriks perbandingan berpasangan kriteria

3. Perhitungan jumlah kolom matriks perbandingan berpasangan kriteria

4. Perhitungan pembagian nilai perbandingan dengan nilai jumlah setiap kolom

5. Hasil nilai pembagian nilai perbandingan dengan nilai jumlah setiap kolom (Eigen)

6. Perhitungan jumlah baris

Hasil perhitungan prioritas pada keseluruhan kriteria tersebut adalah sebagai berikut :

Tabel 4.

Hasil Perhitungan Prioritas Kriteria

\begin{tabular}{|c|c|}
\hline Kriteria & Prioritas \\
\hline Pemahaman & 0,057 \\
\hline Ketelitian & 0,263 \\
\hline Kerajinan & 0,122 \\
\hline Kedisiplinan & 0,558 \\
\hline
\end{tabular}

Setelah diperoleh nilai prioritas kriteria selanjutnya dilakukan perhitungan indek konsisten (Consistency Index), dan konsistensi rasio (Consistency Ratio). a. Perhitungan Consistency Index (CI)

Dalam perhitungan consistency index (CI) menggunakan rumus:

$$
\mathrm{CI}=\frac{\lambda \text { maksimum }-n}{n-1}
$$

Dimana diketahui:

$$
\begin{aligned}
& 0,057\left(\begin{array}{l}
1 \\
5 \\
3 \\
7
\end{array}\right)+0,263\left(\begin{array}{c}
0,2 \\
1 \\
0,33 \\
3
\end{array}\right)+0,122\left(\begin{array}{c}
0,33 \\
3 \\
1 \\
5
\end{array}\right) \\
& +0,588\left(\begin{array}{c}
0,14 \\
0,33 \\
0,2 \\
1
\end{array}\right)=\begin{array}{c}
0,23 \\
1,099 \\
0,49 \\
2,356
\end{array}
\end{aligned}
$$

Keterangan: Matrik yang pertama adalah hasil pembagian matrik perbandingan berpasangan kriteria dan matrik yang kedua adalah matrik hasil prioritas kriteria.

$\lambda$ maksimum

$$
\begin{array}{ll} 
& =\left(\frac{1}{4}\right) \times\left(\frac{0,23}{0,057}+\frac{1,099}{0,263}+\frac{0,49}{0,122}+\frac{2,356}{0,588}\right) \\
& =4,118 \\
\mathrm{n} \quad & =4 \\
\text { maka: } & \\
& \mathrm{CI}=\frac{4,118-4}{4-1}=0,039
\end{array}
$$

b. Perhitungan Consistency Ratio (CR)

Dalam perhitungan consistency ratio (CR) menggunakan rumus:

$$
\mathrm{CR}=\frac{C I}{R I}
$$

Dimana diketahui:

$$
\begin{aligned}
\mathrm{CI}= & 0,039 \\
\mathrm{RI}= & 0,9 \text { (dilihat dari tabel RI dengan nilai } \\
& \mathrm{n}=4) \\
& \text { maka: } \\
\mathrm{CR} \quad= & \frac{0,039}{0,9}=0,044
\end{aligned}
$$

Berdasarkan nilai consistency ratio (CR) $0,044<0,1$ menunjukkan bahwa proses perbandingan dilakukan secara konsisten.

\subsubsection{Perhitungan Prioritas Karyawan \\ Dalam perhitungan prioritas Karyawan} terdapat 10 perbandingan yang harus dilakukan yaitu perbandingan antara Dega dengan Rizky, Dega dengan Ulfa, Dega dengan Dhea, Dega dengan Rani, Rizky dengan Ulfa, Rizky dengan 
Dhea, Rizky dengan Rani, Ulfa dengan Dhea, Ulfa dengan Rani, dan Dhea dengan Rani. Adapun dari ke sepuluh perbandingan tersebut dilakukan sebuah perhitungan yang terdapat pada metode Analytical Hierarcy Process (AHP).

Untuk menghitung hasil penilaian Analytical Hierarcy Process (AHP) yaitu diperlukan rata-rata nilai eigen kriteria dengan rata-rata nilai eigen karyawan di setiap kriterianya. Berikut adalah hasil rata rata nilai eigen kriteria :

Tabel 5.

Nilai rata-rata eigen kriteria

\begin{tabular}{|c|c|}
\hline Kriteria & Rata-rata \\
\hline Pemahaman & 0,057 \\
\hline Ketelitian & 0,263 \\
\hline Kerajinan & 0,122 \\
\hline Kedisiplinan & 0,558 \\
\hline
\end{tabular}

Dan nilai eigen karyawan setiap kriteria adalah :

Tabel 6.

Nilai rata-rata eigen karyawan setiap kriteria

\begin{tabular}{|c|c|c|c|c|}
\hline \multirow{2}{*}{$\begin{array}{c}\text { Krite } \\
\text { ria }\end{array}$} & \multicolumn{5}{|c|}{ Rata-rata } \\
\cline { 2 - 5 } & $\begin{array}{c}\text { Pemaha } \\
\text { man }\end{array}$ & $\begin{array}{c}\text { Ketelit } \\
\text { ian }\end{array}$ & $\begin{array}{c}\text { Keraji } \\
\text { nan }\end{array}$ & $\begin{array}{c}\text { Kedisipli } \\
\text { nan }\end{array}$ \\
\hline Dega & 0,191 & 0,157 & 0,233 & 0,237 \\
\hline Rizky & 0,125 & 0,157 & 0,093 & 0,180 \\
\hline Ulfa & 0,375 & 0,362 & 0,278 & 0,162 \\
\hline Dhea & 0,239 & 0,205 & 0,304 & 0,352 \\
\hline Rani & 0,070 & 0,120 & 0,093 & 0,069 \\
\hline
\end{tabular}

\subsubsection{Perankingan}

Setelah nilai eigen telah didapatkan, maka pada tiap-tiap per kriteria dijumlahkan dan setelah itu ditentukan perankingannya. Nilai yang tertinggi adalah karyawan yang memiliki ranking pertama dan seterusnya. Adapun hasil ranking pada masing-masing karyawan adalah sebagai berikut

Tabel 7.

Hasil ranking pada tiap-tiap karyawan

\begin{tabular}{|c|c|c|}
\hline Karyawan & Nilai & Ranking \\
\hline Dega & 0,213 & 3 \\
\hline Rizky & 0,160 & 4 \\
\hline Ulfa & 0,241 & 2 \\
\hline Dhea & 0,301 & 1 \\
\hline Rani & 0,085 & 5 \\
\hline
\end{tabular}

\subsection{Pembahasan}

3.2.1 Analisis Perhitungan Skor Kriteria dengan Balanced Scorecard

Analisis perhitungan skor kriteria berfungsi untuk mengetahui kriteria mana yang harus diprioritaskan untuk digunakan dalam penentuan karyawan berprestasi berdasarkan nilai skor akhir yang telah dihitung menggunakan metode Balanced Scorecard. Setelah dilakukan wawancara sebelumnya dengan Kepala Bagian Tata Usaha selanjutnya dilakukan penyebaran kuisioner kepada beberapa Kepala Seksi Bagian untuk penentuan kriteria yang akan di prioritaskan dalam penentuan karyawan berprestasi. Dalam rekapan hasil kuisioner tersebut terdapat 4 kriteria yang diantaranya Pemahaman, Ketelitian, Kerajinan, dan Kedisiplinan yang akan dijadikan prioritas dalam penentuan karyawan berprestasi karena memiliki nilai skor akhir tertinggi yang masing- masing kriteria memiliki nilai yang sama yaitu

12,25 .

\subsubsection{Analisis Perhitungan Analytical Hierarcy Process (AHP) Prioritas Kriteria \\ Setelah didapat kriteria yang} diprioritaskan dalam penentuan karyawan berprestasi, maka selanjutnya dilakukan perhitungan prioritas keempat kriteria yang terpilih guna mengetahui kriteria mana harus diprioritaskan berdasarkan nilai bobot prioritas yang telah dihitung menggunakan metode analytical hierarcy process. Setelah dilakukan perhitungan prioritas pada keempat kriteria maka didapatkan hasil kriteria Pemahaman dengan nilai 0,057, kriteria Ketelitian dengan nilai 0,263, kriteria Kerajinan dengan nilai 0,122, dan kriteria Kedisiplinan dengan nilai 0,558. Dari nilai tersebut menunjukkan bahwa Kedisiplinan memiliki nilai tertinggi yang menunjukkan bahwa kriteria Kedisiplinan sangat berpengaruh dalam pemilihan karyawan berprestasi. Nilai consistency Index (CI) prioritas kriteria adalah 0,039 dan nilai consistency ratio $(\mathrm{CR})$ adalah 0,044 yang menunjukkan bahwa $0,044<0,1$ menunjukkan bahwa proses perbandingan dilakukan secara konsisten. 


\subsubsection{Analisis Perhitungan Analytical Hierarcy Process (AHP) Karyawan Terhadap \\ Kriteria \\ Analisis prioritas karyawan bertujuan} untuk mengetahui karyawan mana yang memiliki prestasi tertinggi berdasarkan nilai bobot prioritas yang telah dihitung menggunakan metode analytical hierarcy process. Berikut ini adalah hasil dari perhitungan prioritas karyawan dari masing masing kriteria:

1. Dari hasil kriteria Pemahaman, Dega memiliki nilai 0,191, Rizky memiliki nilai 0,125 , Ulfa memiliki nilai 0,375 , Dhea memiliki nilai 0,239 , dan Rani memiliki nilai 0,070

2. Dari hasil kriteria Ketelitian, Dega memiliki nilai 0,157 , Rizky memiliki nilai 0,157 , Ulfa memiliki nilai 0,362 , Dhea memiliki nilai 0,205, dan Rani memiliki nilai 0,120 .

3. Dari hasil kriteria Kerajinan, Dega memiliki nilai 0,233, Rizky memiliki nilai 0,093, Ulfa memiliki nilai 0,278, Dhea memiliki nilai 0,304, dan Rani memiliki nilai 0,093 .

4. Dari hasil kriteria Kedisiplinan, Dega memiliki nilai 0,237, Rizky memiliki nilai 0,180 , Ulfa memiliki nilai 0,162 , Dhea memiliki nilai 0,352 , dan Rani memiliki nilai 0,069 .

Setelah masing-masing karyawan mendapatkan nilai prioritas dari setiap kriteria selanjutnya adalah penentuan karyawan yang terpilih yaitu dengan cara mengalikan dan menjumlahkan masing-masing kriteria dengan nilai karyawan. Dan diperoleh hasil nilai Dega memiliki nilai 0,213, Rizky memiliki nilai 0,160, Ulfa memiliki nilai 0,241 , Dhea memiliki nilai 0,301, dan Rani memiliki nilai 0,085. Sehingga karyawan berprestasi yang terpilih adalah Dhea karena memiliki nilai terbesar.

\section{Simpulan}

Berdasarkan hasil penelitian yang dilakukan di Kantor Pertanahan Kota Pekanbaru dapat disimpulkan bahwa :

1. Dalam penentuan acuan kritetia dilakukan wawancara dan penyebaran kuisioner terhadap kriteria yang dapat digunakan dalam penentuan karyawan berprestasi dan perhitungan prioritas kriteria dengan menggunakan metode Balanced Scorecard, maka terdapat 4 kriteria yang memiliki skor akhir tertinggi dengan nilai yang sama yaitu 12,25, adapun kriteria yang terpilih sebagai acuan nentuan karyawan berprestasi tersebut adalah :

a. Petugas memahami tugas sesuai pekerjaan yang diberikan (Pemahaman).

b. Petugas mampu menyelesaikan tugas tanpa melakukan kesalahan (Ketelitian)

c. Petugas melakukan tugas sesuai jadwal (Kerajinan)

d. Kehadiran petugas ke kantor dengan baik (Kedisiplinan)

2. Setelah struktur hirarki ditentukan, maka dilakukan perhitungan dengan menggunakan metode AHP untuk mendapat nilai tertinggi dalam menentukan karyawan yang berprestasi pada tiap karyawan terhadap beberapa kriteria terpilih, lalu nilai tersebut dimasukkan ketahap perankingan guna mengetahui karyawan yang berprestasi di bagian Tata Usaha pada Kantor Pertanahan Kota Pekanbaru. Adapun hasil dari perankingan tersebut adalah sebagai berikut :

Tabel 7.

Hasil ranking pada tiap-tiap karyawan

\begin{tabular}{|c|c|c|}
\hline Karyawan & Nilai & Ranking \\
\hline Dhea & 0,301 & 1 \\
\hline Ulfa & 0,241 & 2 \\
\hline Dega & 0,213 & 3 \\
\hline Rizky & 0,160 & 4 \\
\hline Rani & 0,085 & 5 \\
\hline
\end{tabular}

Dalam perangkingan diatas diketahui bahwa Dhea memasuki peringkat pertama dengan nilai 0,301 , Ulfa memasuki peringkat kedua dengan nilai 0,241, Dega memasuki peringkat ke tiga dengan nilai 0,213, Rizky dengan memasuki peringkat ke 4 dengan nilai 0,160 , dan Rani memasuki peringkat 5 dengan nilai 0,085 . 


\section{Daftar Pustaka}

[1] Andri, Erwin, 2011. Pemeringkatan Pegawai Berprestasi di PT. XYZ

[2] Arikunto, Suharsimi. 1998. Prosuder Penelitian Suatu Pendekatan Praktek. Jakarta: PT. Rineka Cipta. Arikunto, Suharsimi. 2006

[3] Daihani, D U. 2001. Komputerisasi Pengambilan Keputusan. Bandung : PT.Elex. Media Komputindo.

[4] Fahmi, Irham.(2010). Manajemen Kinerja. Bandung: Alfabet.

[5] Fajar, (2018). Pengukuran Kinerja Dengan Menggunakan Balanced Scorecard di Pamella 6 Supermarket

[6] Hamid. 2013. Metode Penelitian Pendidikan dan Sosial. Bandung: Alfabeta

[7] Hansen dan Mowen. 2009. Akuntansi Manajerial. Buku 1 edisi 8. Jakarta: Salemba Empat

[8] Kadarsah S., Ali R., 1998, Sistem Pendukung Keputusan suatu wacana struktural idealisasi dan implementasi konsep pengambilan keputusan,

[9] Kaplan, Robert S. dan Norton, David P., 1996, Balanced Scorecard, Menerjemahkan Strategi Menjadi Aksi, Alih Bahasa

[10] Lipe.M.G, and S.Salterio. 2000. The BSC: Judgmental Effect of Common and Unique Performance Measure. The Accounting Review. Vol. 75 (3), pp. 283-298.

[11]Marimin, M.Sc., Prof., Dr., Ir (2004). Teknik dan Aplikasi Pengambil. Keputusan Kriteria Majemuk. Jakarta : PT.Gramedia Widiasarana

[12] Miftahudin \& Yohannes. (2017). Penentuan Strategi Untuk Meningkatkan Kinerja Karyawan di BNI Kantor Cabang Semarang
[13] Monika, (2000). Analisis Penilaian Kinerja Berbasis Balanced Scorecard Pada PT. Petrokopindo Cipta Selaras

[14]Nurlaila, (2006), Perancangan Alat Pengukuran Kinerja Menggunakan Balanced Scorecard di PT. Primissima

[15] Saaty, 1993. Pengambilan Keputusan Bagi Para Pemimpin, Proses Hirarki Analitik untuk Pengambilan Keputusan dalam Situasi yang Kompleks, Pustaka Binama Pressindo.

[16] Saaty, T.L. 2001. Decision Making for Leaders. AHP Series 2.

[17] Singarimbun, Masri dan Shofian Effendi. 1995. Metode Penelitian Survey. Jakarta: LP3ES.

[18] Simon (1960), pengambilan keputusan meliputi empat tahap yang saling berhubungan dan berurutan.

[19] Simon, A. Herbert, (2004), Administrative Behavior, Perilaku Administrasi : Suatu Studi tentang Proses Pengambilan Keputusan dalam Organisasi

[20] Subakti. 2002. Sistem Pendukung Keputusan

[21](Decission Support. System) Surabaya..

[22] Sudirman, Widjajani., 1996, cirri-ciri Sistem Pendukung Keputusan, Gava. Media,Yogyakarta.

[23] Syaifullah. 2010. Pengenalan Metode AHP (Analytical Hierarchy Process).

[24] Umar, 2004, Metode Penelitian Untuk Skripsi Dan Tesis Bisnis, Cet ke 6, Jakarta : PT RajaGrafindo Persada.

[25] Yeni Fitria, (2011). Sitem Pendukung Keputusan Pemilihan Karyawan Berprestasi 